\title{
Brief Report: Violence in Asperger Syndrome,
}

\section{A Critique ${ }^{1}$}

\author{
M. Ghaziuddin, ${ }^{2}$ Luke Tsai, and N. Ghaziuddin \\ University of Michigan Medical Center, Ann Arbor
}

Asperger syndrome was first described by an Austrian physician, Hans Asperger (1944), as "autistic psychopathy." It is an uncommon disorder whose exact prevalence in the general population is not known. Gillberg and Gillberg (1989) estimated that among Swedish children with normal intelligence, the rates are 10 to 26 per 10,000 while among those with mild mental retardation the rate is about 0.4 per 10,000 . It is characterized by social isolation, odd and pedantic speech, poor nonverbal communication, and preoccupation with certain idiosyncratic interests (Wing, 1918). Thus, it shares many features with autism (Kanner, 1943) and also has some overlap with schizoid personality disorder of childhood as described by Wolff and Chick (1980). Although some authorities regard it as a mild variant of autism, others have suggested that the term Asperger syndrome not be used "until and empirically based distinction from higher-level autism can be demonstrated" (Schopler, 1985). While there is still no consensus on its diagnostic features, it is said to differ from autism in its reltively better preserved verbal skills and worse motor development. Although it is proposed to be included in the ICD-10 (World health Organization, 1987), its exact place within the pervasive developmental disorders of childhood is far from clear (Tsai, 1990).

Some recent reports have implied that patients with Asperger syndrome may be predisposed to violent behaivor. Thus, Mawson, Grounds, and Tantam (1985) described a 44-year-old man with a long history of violent behavior which led to frequent psychiatric admissions. He got involved in such violent acts as stabbing a girl in the wrist with a screwdriver because he did not like

'The authors gratefully acknowledge the help of Paulette Lockwood in the preparation of the manuscript.

2Address all correspondence to M. Ghaziuddin, CAPH-0706, University of Michigan Hospitals, 1500 East Medical Center Drive, Ann Arbor, Michigan 48109-0706. 
women drivers, entering a neighbor's house with a knife because he was "upset by the sound a dog was making," assaulting a "crying child on a railway station by putting his hands over its mouth," and so on. He had been diagnosed as suffering from schizophrenia in the past but, based on his developmental history, the authors suggested that the correct diagnosis was one of Asperger syndrome and proposed that the association between Asperger syndrome and violence was more common than generally recognized. Tantam (1988) recruited 60 adults with a history of "life-long eccentricity and social isolation." The sample was drawn from a population of 110 adults referred by psychiatric colleagues. Forty-six cases were diagnosed as "autistic or having an autistic-related disorder such as Asperger syndrome." Six cases showed a morbid fascination for violence. Baron-Cohen (1988) described the assessment of violence in a 21-year-old man with Asperger syndrome, who was frequently violent to his girlfriend and others. He suggested that violence in Asperger syndrome may be related to deficits in social cognition resulting in "an inability to appreciate the mental states" of others. The aim of this paper is to critically evaluate the literature regarding the occurrence of violence in Asperger syndrome.

\section{METHOD}

We undertook an extensive computer-assisted search through September 1990 to identify all published papers on the clinical features of Asperger syndrome since 1944 when that syndrome was first described. Papers listed under Autistic Psychopathy were also included, as this was the title used by Asperger in his original description. Studies that described other aspects of the syndrome or those containing insufficient information were excluded. When multiple studies originated from the same sample, only those studies that dealt with the clinical features of Asperger syndrome were included. An attempt was then made to see how many of the total sample presented with a clear history of violent behavior. For the purpose of this study, violence was defined as any act for which the person could be charged for criminal behavior (such as murder, arson, etc.) or which resulted in a substantial physical injury to another person, with or without the intent to do so. Occasional temper tantrums with nonspecific behavioral problems were not regarded as violent behavior. With the help of cross-references, we inferred that no articles have been published on violence in Asperger syndrome in the non-English literature. Thus, only studies published in the English literature were examined.

\section{RESULTS}

A total of 21 publications were identified which dealt with the clinical features of Asperger syndrome and which did not meet any exclusion criter- 
ia. Of the 12 studies that were excluded, 7 described nonclinical aspects of Asperger syndrome (such as epidemiological and neurocognitive considerations), 3 contained insufficient information, and 2 were part of multiple studies which originated from the same sample. Of a total sample of 132 , only 3 patients $(2.27 \%)$ had a clear history of violent behavior. The results are summarized in Table I.

\section{DISCUSSION}

These results do not support the speculation that violence is common in Asperger syndrome. It may be argued that some of the excluded studies may have contained patients with Asperger syndrome involved in violent behavior. For example, Tantam's (1988) study of 46 adults with "autistic or having autistic-related disorder such as Asperger syndrome," contained 6 subjects involved in violence -3 in assault and 3 in arson. We decided to exclude this study because the criteria for the diagnosis of Asperger syndrome were not clear, the sample consisted of a mixture of autistic or autistic-like individuals and it was not specified as to what diagnostic category the violent patients belonged. Wolff and Chick's (1980) follow-up study of 19 patients with schizoid personality included one violent patient who was in the Scottish State Hospital after assaulting a fellow patient in a psychiatric hospital ward. We decided to exclude this study because as yet there is no consensus that Asperger syndrome and schizoid personality disorder in childhood are one and the same conditions (Tsai, 1990). Littlejohns, Clarke and Corbett (1990) described an 8-year-old boy with a history of "agitation and aggressive outbursts." As no details about the patient's "aggressive outbursts" were given, we did not categorize him as violent. However, even if all the above patients are included, the number of violent patients would rise to 11 out of a total sample of $197(5.58 \%)$. It is not known how many of child and adolescent psychiatric patients are involved in violent behavior as little systematic research has been done in the field of child and adolescent aggression (Garrison et al., 1990). Therefore, comparison cannot be made at this stage between Asperger syndrome and other psychiatric populations, so far as the prevalence of violence is concerned. On the other hand, violence occurs quite commonly in the general population, whose point-prevalence depends on a variety of factors such as age and sex. For example, in the United States, the 1987 rates of violent crimes (rape, robbery, and assault) per 100 persons for the age groups 12-15 years, 16-19 years, and 20-24 years, have been established to be about $6,6.5$, and $7 \%$, respectively (U.S. Bureau of Justice Statistics, 1987). Thus, based on the low number of violent patients with Asperger syndrome estimated on the basis of the above studies and the rela- 
Table I. Violence in Patients with Asperger Syndrome

\begin{tabular}{|c|c|c|c|c|}
\hline Author & $\begin{array}{l}\text { Sample size } \\
(N=132)\end{array}$ & Design & $\begin{array}{l}\text { Violent patients } \\
(n=3)\end{array}$ & Comments \\
\hline Van Krevelin, 1971 & 1 & Case report & - & $\begin{array}{l}\text { Described } 2 \text { siblings, } \\
\text { one had autistic psy- } \\
\text { chopathy and the } \\
\text { other had autism. } \\
\text { Details not given }\end{array}$ \\
\hline Mnukhin \& Isaev, 1975 & 4 & Case report & - & $\begin{array}{l}\text { Described } 4 \text { case vig- } \\
\text { nettes. One had a } \\
\text { history of "aggres- } \\
\text { sive outbursts." De- } \\
\text { tails not given }\end{array}$ \\
\hline Wing, 1981 & 34 & Case series & 1 & $\begin{array}{l}\text { Injured another boy. } \\
\text { Three others } \\
\text { described as indulg- } \\
\text { ing in "bizarre an- } \\
\text { tisocial acts"; but } \\
\text { not clear if these in- } \\
\text { volved violence }\end{array}$ \\
\hline Burgoine \& Wing 1983 & 3 & Case report & - & \\
\hline Gillberg, 1985 & 1 & Case report & - & \\
\hline Mawson et al., 1985 & 1 & Case report & 1 & $\begin{array}{l}\text { Long history of vio- } \\
\text { lent behavior (e.g., } \\
\text { stabbed a girl in the } \\
\text { wrist, assaulted a } \\
\text { crying child). Had a } \\
\text { past diagnosis of } \\
\text { schizophrenia }\end{array}$ \\
\hline Scott, 1985 & 10 & Case control & - & $\begin{array}{l}\text { Both the sample and } \\
\text { the controls showed } \\
\text { "physical aggres- } \\
\text { sion." No details } \\
\text { given }\end{array}$ \\
\hline Volkmar et al., 1985 & 1 & Case report & - & \\
\hline Szatmari et al., 1986 & 1 & Case report & - & \\
\hline Gillberg et al., 1987 & 3 & Case series & - & $\begin{array}{l}\text { Part of a study of } 20 \\
\text { children; } 17 \text { were } \\
\text { autistic; } 3 \text { had } \\
\text { Asperger syndrome }\end{array}$ \\
\hline Goodman, 1987 & 1 & Case report & - & \\
\hline Miles \& Capelle, 1987 & 1 & Case report & - & \\
\hline Munro, 1987 & 1 & Case report & - & \\
\hline Baron-Cohen, 1988 & 1 & Case report & 1 & $\begin{array}{l}\text { 21-year-old male; } \\
\text { repeatedly assaulted } \\
\text { girlfriend and others }\end{array}$ \\
\hline Bowman, 1986 & 2 & Case report & - & \\
\hline Gillberg, 1989 & 20 & Case control & - & $\begin{array}{l}\text { Study of } 23 \text { cases; } 3 \\
\text { of these were includ- } \\
\text { ed in a previous case } \\
\text { report }\end{array}$ \\
\hline $\begin{array}{l}\text { Szatmari et al., } 1989 \\
\text { Carpenter \& Morris, }\end{array}$ & 28 & Case control & - & \\
\hline & 3 & Case report & - & \\
\hline $\begin{array}{l}\text { Jones \& Kerwin, } 1990 \\
\text { Kerbeshian et al., } 1990\end{array}$ & $\begin{array}{r}1 \\
13\end{array}$ & $\begin{array}{l}\text { Case report } \\
\text { Case control }\end{array}$ & - & \\
\hline Littlejohns et al., 1990 & 1 & Case report & - & $\begin{array}{l}\text { Patient showed "agi- } \\
\text { tation and aggressive } \\
\text { outbursts." Details } \\
\text { not given }\end{array}$ \\
\hline
\end{tabular}


tively common occurrence of violence in the general population, we do not believe that any true association exists between the two conditions. The reports of violence in this syndrome could well have resulted from chance.

Another point needing clarification is the exact definition of violence. Distinction needs to be made between violence and "antisocial behavior" because not all antisocial behavior involves violence. For example, Wing's account of 34 cases contained 4 patients involved in "bizarre antisocial acts," out of whom only one injured another patient; details about the other three were not given. If violence can be defined as "physical force used so as to injure, damage, or destroy" (Webster's Dictionary, 1982), is an occasional aggressive outburst or behavioral disturbance justification enough for a person to be labeled violent? It has also been said that patients with Asperger syndrome lack empathy (Mawson et al., 1985) and are therefore incapable of putting themselves into the state of mind of others (Baron-Cohen, 1988). This implies that lack of empathy may be the mechanism underlying violent behavior in Asperger syndrome. While the role of empathy in the occurrence of violence may or may not be important, alternative explanations may be offered. For example, certain neurological disorders such as temporal lobe seizures may occasionally be associated with violence. However, with the possible exception of Mawson et al.'s case, it was not clear if any of the above reports confidently excluded the presence of an underlying organic lesion that might have contributed to the problem.

It has further been claimed that people who come to the attention of secure units because of violence may have Asperger syndrome (Baron-Cohen, 1988). This is reminiscent of the controversy that once raged about the association of violence and XYY syndrome (Pitcher, 1971). Although a prevalence study of Asperger syndrome in prison and on secure units may be worthwhile, what is more urgently needed is a community-based study of the prevalence of violence in this syndrome using clear operationalized criteria. Otherwise, any further speculation on the alleged link between these two conditions will only serve to increase the stigma and distress of the patients and their families.

\section{REFERENCES}

Asperger, H. (1944). Die "autistischen psychopathen" im kindesalter. Archiv für Psychiatrie und Nervenkrankheiten, 117, 76-136.

Baron-Cohen, S. (1988). An assessment of violence in a young man with Asperger's syndrome. Journal of Child Psychology and Psychiatry, 29, 351-360.

Bowman, E. O. (1988). Asperger's syndrome and autism: The case for a connection. British Journal of Psychiatry, 152, 377-382.

Burgoine, E., \& Wing, L. (1982). Identical triplets with Asperger's syndrome. Journal of Autism and Developmental Disorders, 12, 261-265.

Carpenter, P. K., \& Morris, D. (1990). Association of acrocyanosis with Asperger's syndrome. Journal of Mental Deficiency Research, 34, 87-90. 
Garrison, W. T., Ecker, B., Friedman, M., Davidoff, R., Haeberle, K., \& Wagner, M. (1990). Aggression and counteraggression during child psychiatric hospitalization. Journal of the American Academy of Child and Adolescent Psychiatry, 29, 242-250.

Gillberg, C. (1985). Asperger's syndrome and recurrent psychosis-A case study. Journal of Autism and Developmental Disorders, 15, 389-397.

Gillberg, C. (1989). Asperger syndrome in 23 Swedish children. Developmental Medicine and Child Neurology, 31, 520-531.

Gillberg, C., \& Gillberg, C. (1989). Asperger syndrome-some epidemological considerations: a research note. Journal of Child Psychology and Psychiatry, 30, 631-638.

Gillberg, C., Steffenburg, S., \& Jakobsson (1987). Neurobiological findings in 20 gifted children with Kanner-type autism or Asperger syndrome. Developmental Medicine and Child Neurology, 29, 641-649.

Goodman, C. M. (1987). Asperger's syndrome: A case report. Journal of the Royal College of General Practitioners, 37, 414-415.

Jones, P. B., \& Kerwin, R. W. (1990). Left temporal lobe damage in Asperger's syndrome. British Journal of Psychiatry, 156, 570-572.

Kanner, L. (1943). Autistic disturbances of affective contact. Nervous Child, 2, 217-250.

Kerbeshian, J., Burd, L., \& Fisher, W. (1990). Asperger's syndrome: To be or not to be? British Journal of Psychiatry, 156, 721-725.

Littlejohns, C. S., Clarke, D. J., \& Corbett, J. A. (1990). Tourette-like disorder in Asperger's syndrome. British Journal of Psychiatry, 156, 430-433.

Mawson, D., Grounds, A., \& Tantam, D. (1985). Violence and Asperger's syndrome. British Journal of Psychiatry, 147, 566-569.

Miles, S. W., \& Capelle, P. (1987). Asperger's syndrome and aminoaciduria: A case example. British Journal of Psychiatry, 150, 397-400.

Mnukhin, S. S., \& Isaev, D. N. (1975). On the organic nature of some forms of schizoid or autistic psychopathy. Journal of Autism and Childhood Schizophrenia, 5, 99-108.

Munro, A. (1987). A possible case of Asperger's syndrome. Canadian Journal of Psychiatry, $32,465-466$.

Pitcher, D. R. (1971). The XYY syndrome. British Journal of Hospital Medicine, 5, 379-393.

Schopler, E. (1985). Editorial: Convergence of learning disability, higher-level autism, and Asperger's syndrome. Journal of Autism and Developmental Disorders, 15, 359.

Scott, D. W. (1985). Asperger's syndrome and non-verbal communication: a pilot study. Psychological Medicine, 15, 683-687.

Szatmari, P., Bartolucci, G., Finlayson, A., \& Krames, L. (1986). A vote for Asperger's syndrome. Case report [letter]. Journal of Autism and Developmental Disorders, 16, 515-517.

Szatmari, P., Bremner, R., \& Nagy, J. (1989). Asperger's syndrome: a review of clinical features. Canadian Journal of Psychiatri, 34, 554-560.

Tantam, D. (1988). Lifelong eccentricity and social isolation. I. Psychiatric, social and forensic aspects. British Journal of Psychiatry, 153, 777-782.

Tsai, L. Y. (1990). Diagnostic issues inhigh functioning autism. In E. Schopler \& G. B. Mesibov (Eds.), High functioning individuals with autism. New York: Plenum Press.

U.S. Bureau of Justice Statistics. (1987). In Adolescents (Fall 1989). Princeton, NJ: The Robert Wood Johnson Foundation.

Van Krevelen, D. A. R. N. (1971). Early infantile autism and autistic psychopathology. Journal of Autism and Childhood Schizophrenia, 1, 82-86.

Volkmar, F. R., Rhea, P., \& Cohen, D. J. (1985). The use of "Asperger's syndrome." Case report [letter]. Journal of Autism and Developmental Disorders, 15, 437-439.

Webster's Dictionary. (1982). New York: Simon \& Schuster.

Wing, L. (1981). Asperger's syndrome: a clinical account. Psychological Medicine, 11, 115-129.

Wolff, S., \& Chick, J. (1980). Schizoid personality in childhood: A controlled follow-up study. Psychological Medicine, 10, 85-100.

World Health Organization. (1987). International classification of diseases (10th ed.). Draft version. Geneva: Author. 